\title{
Natural Flavonoids in Cancer Treatment
}

\author{
Sandeep Singh ${ }^{1 *}$, Pooja Sharma ${ }^{1,2}$, Dinesh Kumar ${ }^{1}$ \\ ${ }^{\text {IS }}$ ri Sai College of Pharmacy, Manawala, Amritsar-143115, Punjab, India \\ 2 Department of Pharmaceutical Sciences and Drug Research, Punjabi University Patiala, Punjab, India
}

Address for Correspondence: Sandeep Singh; sandhudalpuria@gmail.com

Received:

01.03.2019

Accepted:

25.03.2019

Keywords

Cancer

Prevention;

Flavonoids;

Medicinal Plants.
ABSTRACT: Cancer is a group of diseases involving abnormal cell growth with the potential to invade or spread to other parts of the body. It is a major public health concern in both developed and developing countries. Globally, it's estimated that 42 million people across the world suffered from any of the forms of cancer. This number has more than doubled since 1990. The prevention of Cancer by the use of natural, dietary agents that can reverse or suppress carcinogenic progression, has become an appealing strategy to combat the problem of increasing cases of cancers worldwide. Studies have showed that flavonoids have important effects on cancer chemoprevention and chemotherapy through various mechanisms including Mitigation of oxidative damage, inactivation of carcinogen, inhibition of proliferation and many more. Normal dietary sources like apples, parsley, onions, oranges, tea contain some of the important flavonoids which exhibit anti-cancer properties like luteolin, quercetin, hesperitin, naringenin, epicatechin gallate etc.() 2019 iGlobal Research and Publishing Foundation. All rights reserved.

Cite this article as: Singh, S.; Sharma, P.; Kumar, D. Natural flavonoids in cancer treatment. Indo Global J. Pharm. Sci., 2019; 9(2Suppl.): 113. DOI: http://doi.org/10.35652/IGJPS.2019.92S11 .

Indo Global Journal of Pharmaceutical Sciences( ISSN 2249 1023; CODEN- IGJPAI; NLM ID: 101610675) indexed and abstracted in CrossRef (DOI Enabling), UGC CARE Journal List, EMBASE(Elsevier), National Library of Medicine (NLM) Catalog, ResearchGate, Publons, CAS (ACS), Index Copernicus, Google Scholar and many more. For further details, visit http://iglobaljournal.com

This is a special issue as an outcome of 'RAPSCON-2019' sponsored by APTI and organized by Sri Sai College of Pharmacy, Manawala, Amritsar, Punjab, India. Relaxation offered in journal format. 